\title{
Performance and Emission Characteristics of Dual Biofuel (CNSL and Rice Bran Oil) Blended With Diesel in CI Engine
}

\author{
Sangeetha Krishnamoorthi, M.Prabhahar, G.R.Muthu Kumar, Saberrish.S, Solai Raja.R
}

\begin{abstract}
In recent trends due to the increase in rate of petrol and diesel prices biodiesel has been used as an alternate fuel in many of the fast developing countries. However in our country also many research work has been done using different oils. In this paper instead of using a single oil, two different oils was mixed with diesel in different blends and the emissions were calculated and the results were plotted. The two different oils used was the Cashew nutshell liquid (CNSL) and the Rice bran oil. Cashew oil is found to be a by-product which is available from the Cashew industry and after the transesterification process the cardanol obtained was used without any modifications. Rice bran oil is mostly found in the places where rice is grown in a huge quantity and more number of research works has not been done in this oil. By the transesterification process the rice bran oil was prepared and mixed with the CNSL in the different proportions, which was also mixed with diesel in some amounts and the different characteristics were evaluated and plotted.
\end{abstract}

\section{Keyword: CNSL, Rice bran oil, CI Engine}

\section{INTRODUCTION}

The Variable Compression Ratio engine has been constantly used in different fields especially in the commercial purposes due to its construction which can undergo high pressures during the operating speed. Not only the cylinder head but also the piston crown can also be modified in the VCR engine. The flow of fuel can be controlled at different load conditions with the help of a governor. The VCR engine at even low engine power levels has a high efficiency. Coefficient of variance and burning rate was the two advantages of the VCR engine which leads to do more research by using different oils. In the VCR engine all the different characteristics were measured and the graphs were plotted. The values of diesel engine was compared with the given biofuel and the performance and emission characteristics were found out and compared. The applications of loads were four levels and they were 0,3,6 and $9 \mathrm{kgs}$ respectively. At a speed of $1800 \mathrm{rpm}$ the engine speed

Revised Manuscript Received on September 22, 2019

* Correspondence Author

Sangeetha Krishnamoorthi -Associate Professor, Department of Mechanical Engineering, Aarupadai Veedu Institute of Technology, Vinayaka Mission Research Foundation, Deemed to be University sangeethas@avit.ac.in

Dr. M.Prabhahar - Professor, Department of Mechanical Engineering,

Aarupadai Veedu Institute of Technology, Vinayaka Mission Research Foundation, Deemed to be University mprabhahar@gmail.com

G.R.Muthu Kumar, Saberrish.S, Solai Raja.R, UG Scholar, Aarupadai Veedu Institute of Technology, Vinayaka Mission'S Research Foundation was fixed for different load levels. At each different levels of load the Brake specific fuel consumption, Brake thermal efficiency and different emissions along with smoke density were recorded and the graph was plotted. The Table 1 provides the specification of the engine used in the analysis.

Table 1 Specifications of the engine

\begin{tabular}{|c|c|}
\hline MANUFACTURER & APEX INNOVATIONS PVT. LTD \\
\hline Engine & $\begin{array}{l}\text { TYPE : 1Cylinder,4 Stroke, Water cooled, } \\
\text { Stroke } 100 \mathrm{~mm} \text {, bore } 87.5 \mathrm{~mm} \text {, capacity } 661 \mathrm{cc} \\
\text { Diesel Mode: Power } 3.5 \mathrm{KW} \text {, Speed } 1500 \mathrm{rpm} \text {, } \\
\text { CR range } 12: 1-18: 1 \text {, Injection variation 0-25 } \\
\text { Deg BTDC } \\
\text { ECU Petrol mode:3.5 KW @ } 1500 \mathrm{rpm} \text {, Speed } \\
\text { range } 1200-1800 \mathrm{rpm}, \mathrm{CR} \text { range } 6: 1-10: 1\end{array}$ \\
\hline Dynamometer & $\begin{array}{l}\text { Type eddy current, water cooled, with loading } \\
\text { unit }\end{array}$ \\
\hline Fuel tank & $\begin{array}{l}\text { Capacity } 15 \text { lit, Type: dual compartment, with } \\
\text { fuel metering pipe of glass }\end{array}$ \\
\hline Piezo sensor & $\begin{array}{l}\text { Combustion range } 500 \text { PSI, with low noise cable } \\
\text { Diesel line: Range } 500 \text { PSI, with low noise } \\
\text { cable }\end{array}$ \\
\hline Crank angle sensor & $\begin{array}{l}\text { Resolution } 1 \text { Deg, speed } 5500 \mathrm{rmm} \text { with TDC } \\
\text { pulse }\end{array}$ \\
\hline Data acquisition device & NI USB $-6210,16 \mathrm{bit}, 250 \mathrm{ks} / \mathrm{s}$ \\
\hline Engine control hardware & Fuel injector, fuel pump, ignition coil \\
\hline Temperature sensor & Type RTD,PT100 and Thermocouple \\
\hline Load indicator & Digital, range $0-50 \mathrm{Kg}$, supply $230 \mathrm{VAC}$ \\
\hline Load sensor & Load cell , type strain gauge, range $0-50 \mathrm{Kg}$ \\
\hline Software & $\begin{array}{l}\text { "Engine soft" Engine performance analysis } \\
\text { software }\end{array}$ \\
\hline
\end{tabular}

\section{LITERATURE REVIEW}

Ali Keskin and Duran Altiparmak et.al (2008) studied the biodiesel was produced by reacting cotton oil soapstock with methyl alcohol at determined optimum condition. The cotton oil biodiesel-diesel fuel blends were tested in a single cylinder direct injection diesel engine. B. Baiju and M.K. Naik et.al (2007) have investigated that the major problem of using neat Karanja oil as a fuel in a compression ignition engine arises due to its very high viscosity. Transesterification with alcohols reduces the viscosity of the oil and other properties have been evaluated to be comparable with those of diesel. K. Pramanik (2003) studied the properties and use of jatropha oil and diesel fuel blends in compression ignition engine. In the present examination the high thickness of the jatropha oil which has been considered has a potential elective fuel for the pressure start (CI)motor was diminished by mixing with diesel. The mixes of fluctuating extents of jatropha oil and diesel were arranged, dissected and contrasted with diesel fuel. Sanjay patil (2012) analysed that the use of straight vegetable oils in CI engine for long term deteriorates the engine performance and is mainly because of higher viscosity. The best way to use vegetable oils as fuel in CI 


\section{Performance and Emission Characteristics of Dual Biofuel (CNSL and Rice Bran Oil) Blended With Diesel in CI Engine}

engine is to convert it into biodiesel.

\section{RESULTS \& DISCUSSION}

The graphs were plotted between the different blends and for easy understanding it is denoted as First blend (Diesel 80+CNSL B10+RBO B10), Second blend (Diesel 60+CNSL B20+RBO B20), Third blend (Diesel 40+CNSL B30+RBO B30).

Fig.1 shows the variation in the Brake specific fuel consumption for different blends of CNSL and RBO mixed with diesel and the graph was plotted for different BP of 0 to 9 $\mathrm{KW}$. The maximum load BSFC values for first blend was $0.33 \mathrm{Kg} / \mathrm{Kw}-\mathrm{hr}$, for second blend was $0.33 \mathrm{Kg} / \mathrm{Kw}-\mathrm{hr}$ and for third blend was $0.29 \mathrm{Kg} / \mathrm{Kw}-\mathrm{hr}$.

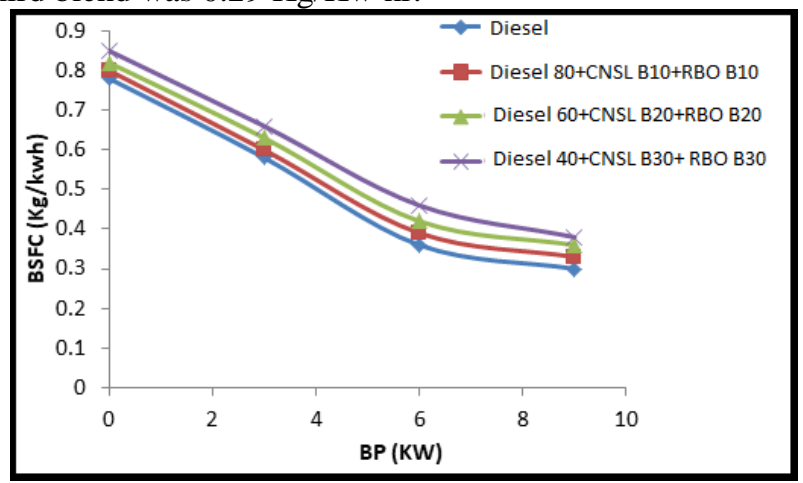

Fig.1 BSFC vs BP

The Brake thermal efficiency for different blends of CNSL and RBO mixed with diesel and the graph was plotted for different $\mathrm{BP}$ of 0 to $9 \mathrm{KW}$ is shown in the fig. 2. The maximum load BTE values for first blend was $27.8 \%$,for second blend was $26 \%$ and for third blend was $34.1 \%$.

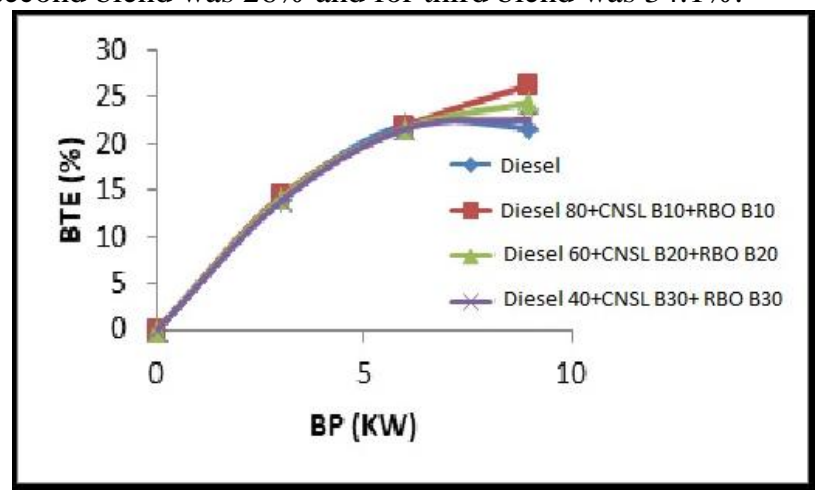

Fig.2 BTE vs BP

Fig. 3 shows the plot between Carbon monoxide emission with brake power. The maximum emission for first blend was $0.03 \% \mathrm{Vol}$, second blend was $0.02 \% \mathrm{Vol}$, and for third blend was $0.05 \%$ Vol.

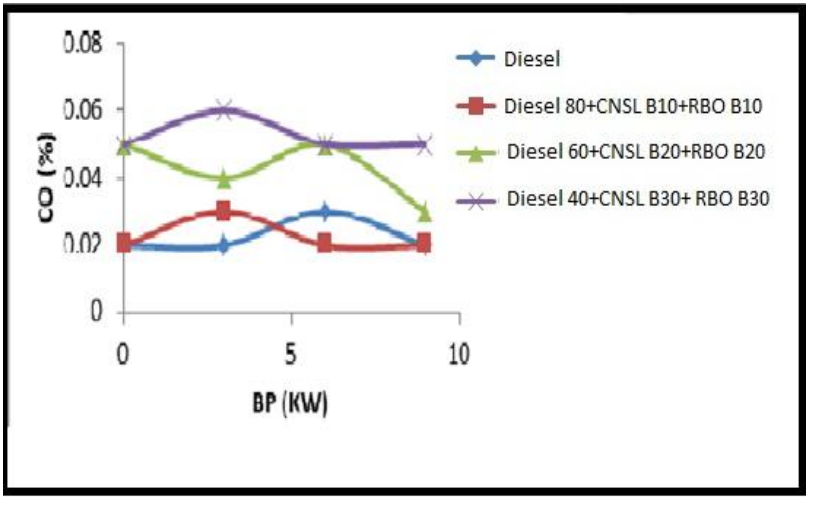

Fig.3 CO vs BP
Fig. 4 shows the variation in Nitrogen oxide for different blends of CNSL and RBO mixed with diesel and the graph was plotted for different $\mathrm{BP}$ of 0 to $9 \mathrm{KW}$. The NOX values for biodiesel is always higher than diesel for all the different blends.

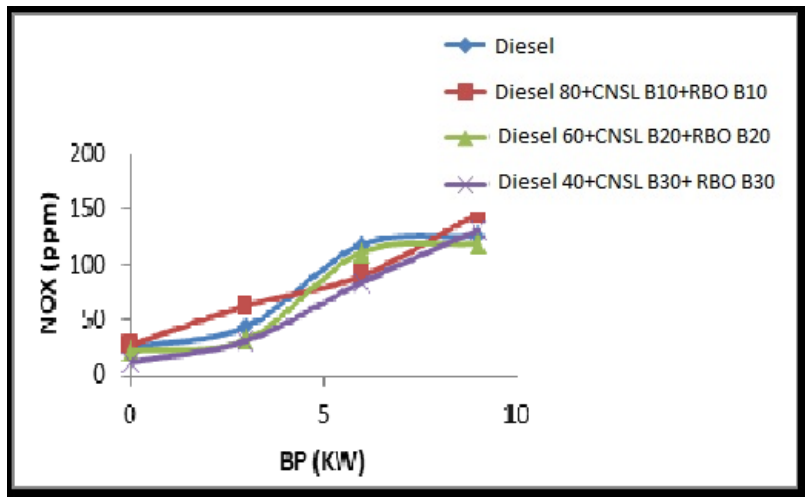

Fig.4 NOX vs BP

Fig. 5 shows the variation in Smoke density for different blends of CNSL and RBO mixed with diesel and the graph was plotted for different BP of 0 to $9 \mathrm{KW}$. The maximum values of smoke for first blend was $31.5 \%$, for second blend was $41.6 \%$ and for third blend was $48.5 \%$.

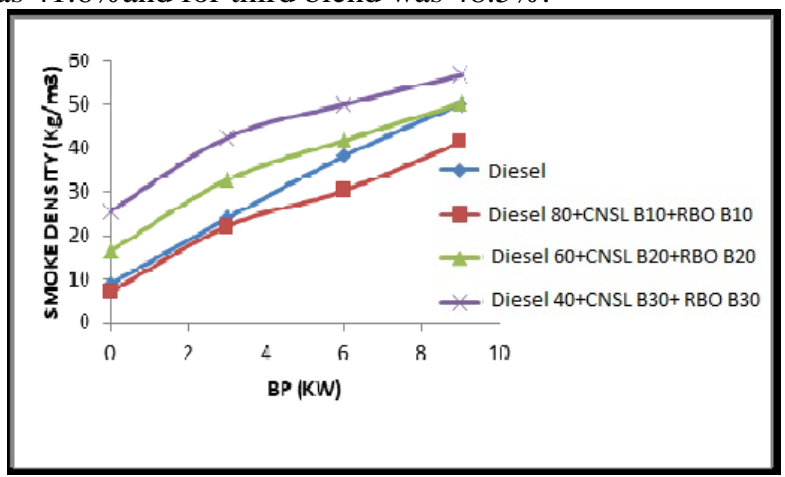

Fig.5 Smoke vs BP

Fig. 6 shows the variation in Hydrocarbon emission for different blends of CNSL and RBO mixed with diesel and the graph was plotted for different $\mathrm{BP}$ of 0 to $9 \mathrm{KW}$. The $\mathrm{HC}$ emission values was found to be nearer to the diesel values.

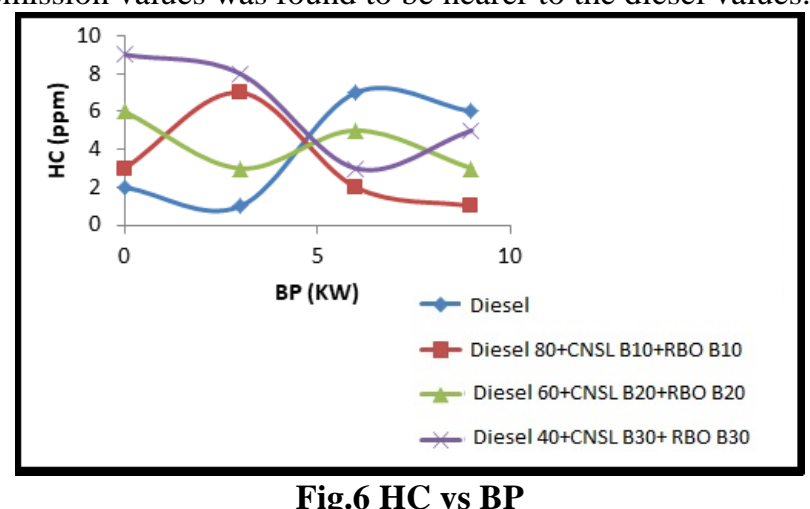

\section{CONCLUSION}

The CNSL and RBO oil when mixed with diesel has shown a various changes in the values when comparing with diesel. The value of Brake specific fuel consumption was found to be nearer to the diesel for lower blends compared to the higher blends. The Brake thermal efficiency was for the blend the Diesel $60+$ CNSL 20+ RBO 20 was found to be lower than the other blends. The emission

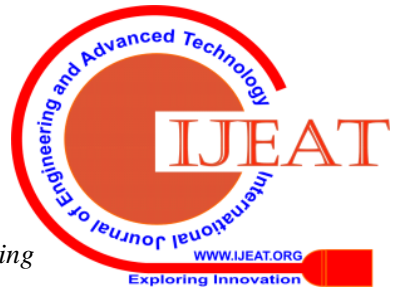


values were also nearly comparable with diesel for the lower blends. Thus it can be concluded that with a diesel of about 60 and the other two oil with a ratio of about 20 can be used in the $\mathrm{CI}$ engine without any change in the engine.

\section{REFERENCES}

1. Ali Keskin, et. al., "Using of cotton oil soapstock biodiesel- diesel fuel blends as an alternative diesel fuel" Renewable energy, Science direct, Elsevier, Vol 33., April 2008., pp 553-557

2. K.Pramanik., "Properties and use of jatropha curcas oil and diesel fuel blends in CI engine" Renewable energy, Science direct, Elsevier, Vol. 28., Feb 2003., pp 239-248

3. Jalpesh Solanki H. and Tushar Javiya V. (2002) "Cashew nut shell liquid fuel as substitute for diesel fuel to be used in C.I engine". International Journal of Advanced Research in Science, Engineering and Technology, Vol.01, pp. 8-12.

4. Sanjay Patil "Computer modelling of CI engine performance for parametric study of injection timing fuelled with POME and its blends with diesel", IJERT, Vol. 1, Sep 2012

5. M. Saravanakumar, M. Prabhahar, Sangeetha Krishnamoorthi and S. Sendilvelan "Emission Characterristics of Biodiesel Derived From Used Cooking Oil Blended With Diesel In The Presence of Potassium Hydroxide (KOH) Catalyst As Alternative Fuel For Diesel Engines" In Journal of Rasayan J. Chem., Volume 11 No.1 , pp. 372-377, 2018

6. Damodhar Garka J. and Ramesh Bhande S. (2014) "Review on extraction and isolation of cashew nut shell liquid", International Journal of Innovations in Engineering Research and Technology(IJIERT), Vol.1.

7. M. Prabhahar, S. Sendilvelan and J. Francis Xavier "Effect of Dimethoxy-Methane $\left(\mathrm{C}_{3} \mathrm{H}_{8} \mathrm{O}_{2}\right)$ On Combustion Characteristics Of A Direct Injection Diesel Engine With Variable Compression Ratio Fuelled With Biodiesel Blends With Diesel $\left(\mathrm{C}_{10.8} \mathrm{H}_{18.7}\right)$ Journal of Oriental Journal of Chemistry Vol 33, No 6, 2017

8. Murugasen A., Umarani C., Subramanaiam R. and Neduchezhian N. "Bio diesel as an Alternative Fuel for Diesel Engine - A Review", International Journal of Renewable and Sustainable Energy Review 2007.

9. S. Nallusamy (2003) "Experimental analysis of emission characteristics using CNSL biodiesel in dual fuel mode", https://www.researchgate.net/publication/293555771

10. Murugesan A. (2009) 'Experimental and theoretical Investigation of using Biodiesel in Diesel Engines; Ph.D., Thesis. Anna University, CHENNAI.

11. Raghavendra Prasad S.A (2009) "A review on CNSL biodiesel as an alternative fuel for diesel engine”, International Journal of Science and Research (IJSR).

12. Sundarapandian and Devaradjane, "Performance and Emission Analysis of Bio Diesel Operated CI Engine", Journal of Engineering, Computing and Architecture. Internal Combustion Engines - John B. Heywood 